\title{
Computer Modelling and Identification of Factors Important for the Success of Business Clusters.
}

\author{
M. Al-kfairy, S. Khaddaj and R. B. Mellor. ${ }^{1}$ \\ Computing and Maths, Kingston University, London, UK. \\ $1=$ corresponding author at r.mellor@kingston.ac.uk
}

\begin{abstract}
Business clusters are often intended to provide the environment needed to stimulate the financial growth of corporate inhabitants. However, many fails, prompting scholars to strive to identify the relevant success factors. In this paper, we identify factors promoting the growth of high-technology firms using a longitudinal dataset for both on- and off-cluster firms in Mjärdevi Science Park (MSP) at Linköping, Sweden. A panel data approach was used to investigate factors influencing the growth of on-cluster firms using off-cluster firms as a control group. Size and age influence turnover, as does the ability to innovate, but whereas size and age have a quadratic (non-linear) impact on financial growth, innovation capabilities have a positive linear impact. Employment is mainly correlated to age, previous years' innovation and shareholder investment. Innovation output, (the ratio of patents asset value to turnover) is correlated to networking measured as social expenditure, which in turn exhibits a positive influence on innovation capabilities.
\end{abstract}

Keywords: Business Clusters, Innovation Networks, Science Parks, Success Indicators, Success Factors

Reference to this paper should be made as follows: Author. (xxxx) 'Title', Int. J. xxxxxxxxxxx $x x x x x x x x x x x$,

\section{Introduction}

Business clusters are used as tools in regional development aimed at fostering innovation through knowledge spill-over and networking between firms (Kim et al., 2014). They are often built as part of a local government vision to enhance regional prosperity by stimulating employment and economic income (Cojocaru and Ionescu, 2016). Recently, the designation Science and Technology Parks (STP) has become a common form of terminology, although technopolis, catapult, silicone-something, research /science /technology/ park, business cluster, tech-hub, etc (all with or without incubators) are used relatively interchangeably. The International Association of Science Parks and Areas of Innovation (IASP) reported 353 members in 76 countries hosting over 142000 client firms (IASP, 2016). A successful example of an STP brings different benefits for its client firms e.g. knowledge spill-over, networking with venture capitalists (VCs), networking with Higher Education Institutes (HEIs), which in turn provide firms with the expertise they need and updated technologies, standards, and practices in the field (Cojocaru and Ionescu, 2016). State investment in STPs can be significant. For example, 
Wallsten (2004) reported that in 1999 Hong Kong invested 2 billion dollars in building a science park. Many business clusters have tried to imitate Silicon Valley, and many have failed. Wadhwa (2013 pp.87) said: "Sadly, the magic never happened-anywhere. Hundreds of regions all over the world collectively spent tens of billions of dollars trying to build their versions of Silicon Valley. I don't know of a single success". Moreover, as Guadix et al., (2016 pp.4871) argued: "A number of authors propose a possible explanation to reconcile these two different points of view: the parks are heterogeneous. Some parks work properly and generate values for hosted companies, whereas others are not successful".

Recently 6 out of 10 tech-hubs were closed in Wales, at considerable cost to the UK taxpayer (Pugh et al., 2018; BBC, 2010), and in African tech-hubs a World Bank report found a closure rate of $26 \%$ and, while many hangs on surviving, the rate of clear success was around 20\% (Kelly and Firestone, 2016). Clearly, it would be advantageous to know what success factors can be, but even studies comparing on-cluster and offcluster firms show contradicting results (Hobbs et al., 2017).

A simulation study of the organizational architecture of business clusters shows the importance of the cluster networking topological structure. At early stages optimal knowledge flow between cluster firms and the central Cluster Initiative (CI) is needed, after which, and upon the STP becoming better established, the cluster can then move into randomly-connected/strongly connected structures (Al-kfairy et al., 2019). However, there may be many other factors that influence the success of STPs and their inhabitants, like the concept of "ambidexterity" (see e.g. Will et al, 2019).

In previous work - at the aggregate level - Al-kfairy et al. (2018) showed that on average, on-cluster firms spend much more on R\&D and social expenditure than offcluster firms, which in turn is correlated with an improved on-cluster innovation performance and indeed that the larger the on-cluster firm is, then the greater the value of its patents and licenses becomes.

To investigate the characteristics of on-cluster firms further, we used real data from a successful large and mature business cluster, Mjärdevi science park (MSP) in Linköping, Sweden, aiming to identify factors that influence the success of its inhabitants (client firms). To do this, we followed the approach defined by Diez-Vial and FernándezOlmos (2017) and applied a longitudinal data analysis to on-cluster firms and pertaining to the growth of firms' (employment and turnover), and innovation. However, in contrast to previous work, the analysis presented here was performed at the micro-level instead of at the aggregate-level. This enables us to pose the research question "Which distinctive factors promote innovation, financial and size growth in on-cluster firms". To answer this, we used off-cluster firms as a control group.

This study starts by considering the theoretical foundations (section 2) showing how researchers judge the performance of business clusters and extracted success indicators, followed by a description of the data used, methodology (section 3), and the results in section 4 . In section 5 policies and research implications are discussed. 


\section{Business Clusters: Success Factors and Indicators}

Knowledge sharing through networking between firms working in the same or similar industries is the most cited benefit arising from inhabiting a cluster/STP because it stimulates innovation (Porter, 2003; Porter, 1998; Porter, 2000). Different types of knowledge bring different benefits, for example, tacit knowledge moving through formal and informal channels is mostly beneficial for product innovation, while codified knowledge contributes to process innovation (Casanueva et al., 2013; Bell, 2005; Eisingerich et al., 2010). Both product innovation and processes innovation are believed to be significant success factors for high-tech firms. In a companion paper, we reported that clusters with a "star" topological structure are beneficial during early cluster development, while strongly connected and randomly connected structures are more beneficial when a business cluster is well-established (Al-kfairy et al., 2019; see also (Markusen, 1996).

Several approaches were proposed for measuring innovation levels in on-cluster firms; expenditure on R\&D (García-Manjón and Romero-Merino, 2012), R\&D volatility (Mudambi and Swift, 2011), and, most recently, R\&D ratio to turnover (Diez-Vial and Fernández-Olmos, 2017). Networking is another metric used and Morosini (2004) and Pitelis (2012) reported a positive impact of network intensity i.e. the more central to the network a firm is, the more innovative it is. Computer models also show that "just-intime" knowledge acquired by networking between firms is almost as valuable as endogenous innovation (see (Mellor, 2014a; Mellor, 2015; Mellor, 2014b) although it is acknowledged that this is probably not a universal measure of innovation output (see e.g. Mellor (2019) and Delgado el al. (2010).

Nonetheless, R\&D expenditure on its own suffers from being a poor metric because spending on R\&D might not have any effect on innovation, or only have an effect a variable number of years later (Baptista and Swann, 1998; Lamperti et al., 2015). Moreover, it is very hard to measure a firms' network intensity or openness plus that they should be considered as a cause of innovation and not as an innovation output. Thus the actual factors which influence innovation for on-cluster firms are not known with any great certainty.

In this work, innovation input is measured in two ways; as R\&D ratio to turnover, as well as networking (as social expenditures ratio to turnover). Innovation output is the ratio of the book value of patents to turnover. These metrics enable us to measure what is the actual innovation input is, as well as what is the actual innovation output. Diez-Vial and Fernández-Olmos, (2017) also used R\&D ratio to measure innovation input, but they used the values of new products as innovation output, and new products values are not available in the Ratsit database. Others have used different metrics e.g. Porter (2003) used number of patents only but many young firms rely on trade secrets, or may even apply for "blocking patents" to confound rivals. In addition, we observe a new factor, which is based on the relationship between the social expenditure ratio to turnover and its impact on innovation output (see the results section 4.3). Overall, the choice of factors is 
driven by literature review, experts' views and the availability of data, as not all factors that can be considered are available in the Ratsit database.

Financial performance is another indicator used to assess the performance of business clusters. Because the firms involved vary widely in e.g. age and size, a much more nuanced approach is required, and this involves going to the micro-level. Previous micro-level studies have assessed parameters such as sales growth (García-Manjón and Romero-Merino, 2012), salary growth (Porter, 2003) and firms' profitability and turnover (Temouri, 2012). However, salary growth is a poor metric because for example start-ups can be established by employees of other firms, who may still be working elsewhere, or working for a capped salary due to personal tax issues, etc. Moreover, knowledge-based firms normally need some time to start generating profits (Folta et al., 2006), while sales growth metric was not available in the dataset. Thus, this study focuses on turnover growth as a way of measuring financial performance because it also encompasses financial injections rather than simple product sales. We segment the data according to relevant factors; firm age, firm size, innovation capabilities, shareholders investments, and group contributions (where part of a group).

We apply the same micro-level approach for another proposed metric of measuring firms' performance inside business clusters; employment and employment growth (Temouri, 2012; Scoreboard, 2015). Previous studies strive to connect innovation with growth in patents and sales growth (Delgado et al., 2014; Delgado et al., 2010) or networking, and networking intensity with employment and turnover growth (Kajikawa et al., 2010; Kim et al., 2014), or venture capital investments and employment and sales growth as (Davila et al., 2003; Grilli and Murtinu, 2014). As mentioned earlier, we developed an approach initially similar to that of Diez-Vial and Fernández-Olmos (2017) using on- and off-cluster firms, where off-cluster firms act as a control group, and then construct econometric models by including different variables. The variables used by Diez-Vial and Fernández-Olmos (2017) were: firms' age, product innovation, firms' growth using its sales growth and employment growth using panel data analysis and linear models. The purpose of their study was to extract the impact of firms' sizes and age on the overall firms' performance inside business clusters, which helps identifying if these factors have different impact on firms' location. Our approach differs as it includes variables such as group contribution (investment), shareholders' contribution, social expenditure, used as a measure of networking and also controlling for non-linear models over the range of firm size and age.

In summary the work presented in this paper explores all the indices that are available in the Ratsit dataset, including: firms' ages, shareholders' investments, group contributions, firm sizes, R\&D expenditures, social expenditures, patents value, turnover, firm sizes, and time effect (as the previous year's effect on turnover).

\section{Methodological Approach and Econometric Models}

Panel data analysis techniques, with fixed and random effects, were used with off-cluster firms as a control group. Panel data analysis was previously used in identifying if on- 
cluster firm are more innovative than off-cluster firms with industrial and individual fixed effect (Baptista and Swann, 1998), and cluster industrial innovation growth (Delgado et al., 2014; Delgado et al., 2010). Earlier studies highlight the advantages of using Panel data analysis which can be summarized as; it builds better inference models due to its high degree of freedom, it helps in building and test more complex models (than normal linear regression models), helps controlling for the variables which are not part of the model, and helps in reducing collinearity between different model variables, which makes it more dynamic than e.g. time series models (Hsiao, 2007).

\subsection{Methodological Approach}

A longitudinal dataset for the years 2007 - 2015 of firms using industrial code ' $62 \mathrm{X}$ ' (programming and related industries) was collected from Swedish companies' database 'Ratsit' for all companies located in Linköping municipality (Klofsten et al., 2015). Firms were divided into two groups (on-cluster and off-cluster), where on-cluster was defined using the following three criteria:

1. Located on the main streets of MSP, which are Datalinjen, Teknikringen, Diskettgatan, Wallenbergsgata and Universitetsvägen,

2. Or is part of MSP community as mentioned on its website,

3. Or is part of The Foundation for the Development of Small Businesses in Linköping (SMIL) organization (which is the sister organization to the MSP community).

Otherwise, the company was declared off-cluster. A binary variable called On-Cluster was assigned to each firm, which was 1 if the firm is located on-cluster, or 0 if the firm is off-cluster.

In addition, data was categorized year by year and represents the following: age/year, number of firms, number of employees, $R \& D$ expenditure, social expenses, firm age, turnover, and the accumulative value of patents and licenses as assets. All data, except for the number of employees and firm age were reported in KSEK (Thousands Swedish Krona).

Panel data regression was applied for evaluating the variables contributing towards the financial and employment growth of firms as well as their innovation capabilities using the Stata 14 statistical software package. The resulting models obtained were checked against the off-cluster group to understand if there are any differences in the success indicators on- and off-cluster. The Hausman test was applied to select between fixed and random effect models, as well as tests for time fixed effect. The following steps were followed for running regression analyses:

1. The on-cluster dataset was loaded into Stata.

2. A unique identifier was set using the organization number and the time (year) of the data point.

3. The associated number of employees, and turnover were transformed using the natural logarithmic functions $(\ln (\mathrm{x})$, where $\mathrm{x}=$ number of employees or turnover). 
Author

4. As previously (Diez-Vial and Fernández-Olmos, 2017) the total value of the variable 'patents ratio to the turnover' was used to represent innovation

5. The models were built using Stata, where both linear and quadratic models were tested. Variables were added one by one, and, as before (Torres-Reyna, 2007) pvalues were derived each time a new variable was added. The selection of the best fit model was based on trial and error methodology using a number of factors which are summarized as follows:

I. Previously identified in the literature as being of possible interest.

II. Variables being added individually and either accepted as part of the model or rejected, based on its $\mathrm{p}$-value, where ( $p$-value $>0.05)$ is rejected.

III. Variables were tested using both linear and quadratic models using both the overall generated $p$-values and $R^{2}$-adjusted values. If the $p$-value is significantly improved using the quadratic model (e.g. being rejected with linear model and reporting a $p$-value $>0.05$ while quadratic model reported a better $p$-value $<0.05$, which means it was statistically insignificant with linear model and becomes statistically significant with quadratic model), then quadratic model is used, otherwise if ( $p$-value $<0.05)$ and $R^{2}$ adjusted value was not significantly improved then linear models are assessed: Both the overall model $p$-value and the coefficient $p$ value, and evaluate both of them, as both must be less than the cutoff point of 0.05 .

6. The Hausman test was used to select between fixed and random effect models.

7. We tested for time fixed effect as previously described by (Torres-Reyna, 2007).

8. Steps 2-5 were repeated for the off-cluster firms and if significant $p$-values were found, then steps 6 and 7 were also applied.

This helps identify the actual factors influencing firms' development at the micro level for both on- and off-cluster firms, the next section will go through the econometric models using the aforementioned steps.

\subsection{Firms Employment growth}

The growth of the firm was evaluated against firms age, innovation output, shareholders investments and (in term of group investment), group contributions. Both linear and quadratic regressions using the absolute values, the final equation is shown as equation 1:

$$
\ln \left(e m p_{i, t}\right)=B_{1} \times \operatorname{Age}_{i, t}^{2}+B_{2} \times A g e_{i, t}+B_{3} \times \operatorname{Innov}_{i, t-1}+B_{4} \times S C_{i, t-1}+U_{i}+C \quad \text { Eq. } 1
$$

Where Age is the firm age at the time of assessment, $S C$ is the shareholders contributions in previous year $(t-1), U_{i}$ is firms' specific effect, and Innov is the previous year innovation calculated as the following: 
Innov $_{i, t}=\frac{T P V_{i, t}}{\text { Turnover }_{i, t}}$

Eq. 2

And (equation 2) where $T P V=$ the total book value of patents of firm $i$, in year $(t)$.

The Hausman test was applied to decide if random effect is more appropriate than fixed effect because this has previous been found to be good practice (Torres-Reyna, 2007). The test reported $\left(c h i^{2}=0.2728\right.$, failure to reject the null hypothesis), which indicates that random effect model must be used. The Breusch and Pagan Lagrangian multiplier test were applied for random effects vs OLS regression, which reports (Prob > $c h i^{2}=0.0000$, rejecting the null hypothesis), and conclude that random effect is the most appropriate model. This indicates that there are no correlations between the independent variables (Age, Innova, and $S C$ ) with individual specific effect (each organization is different from each other with a factor of $U_{i}$ relative to the first organization). The model reported a $U_{i}$ between minimum $=-2.181455$, and maximum $=$ 2.759062. This means that the effect on employment growth in individual firms can be either negative or positive and that this is specific to each organisation. Values were obtained by running different regressions, which reports (almost) the same coefficient, thus we used the $R^{2}=91 \%$, and $R^{2}$-adjusted $=89 \%$ as given by the OLS regression.

Table 1: The employment growth for on-cluster firms showing fixed and random effects as obtained from the parameter coefficient from Eq 1.

\begin{tabular}{|l|l|l|}
\hline Parameter & $\begin{array}{l}\text { Fixed Effect } \\
\text { Coefficient(p-value) }\end{array}$ & $\begin{array}{l}\text { Random Effect } \\
\text { Coefficient (p-value) }\end{array}$ \\
\hline B1 $\left(\mathrm{Age}_{\mathrm{i}, \mathrm{t}}{ }^{2}\right)$ & $-0.002864(0.000)$ & $-0.002580(0.000)$ \\
\hline $\mathrm{B} 2\left(\mathrm{Age}_{\mathrm{i}, \mathrm{t}}\right)$ & $0.118949(0.000)$ & $0.116393(0.000)$ \\
\hline $\mathrm{B} 3\left(\mathrm{Innov}_{\mathrm{i}, \mathrm{t}-1)}\right)$ & $0.014658(0.009)$ & $0.146333(0.009)$ \\
\hline $\mathrm{B} 4\left(\mathrm{SC}_{\mathrm{i}, \mathrm{t}-1}\right)$ & $0.000071(0.009)$ & $0.000068(0.011)$ \\
\hline Constant & $1.166648(0.000)$ & $1.007337(0.000)$ \\
\hline
\end{tabular}

Table 1 presents the values of the coefficients and shows a positive correlation (linear) between last year innovation output and employment growth and similarly between previous year shareholders contributions and employment growth. However, the model presents a more complex (quadratic) relationship between firms' ages and employment growth. 
Table 2: The employment growth pertaining to off-cluster firms as obtained by applying Eq. 1.

\begin{tabular}{|l|l|l|}
\hline Parameter & $\begin{array}{l}\text { Fixed Effect } \\
\text { Coefficient (p-value) }\end{array}$ & $\begin{array}{l}\text { Random Effect } \\
\text { Coefficient (p-value) }\end{array}$ \\
\hline $\mathrm{B} 1\left(\mathrm{Age}_{\mathrm{i}, \mathrm{t}}\right)$ & $0.000052(0.881)$ & $-0.000019(0.954)$ \\
\hline $\mathrm{B} 2\left(\mathrm{Age}_{\mathrm{i}, \mathrm{t}}\right)$ & $0.005044(0.603)$ & $0.010581(0.244)$ \\
\hline $\mathrm{B} 3\left(\mathrm{Innov}_{\mathrm{i}, \mathrm{t}-1}\right)$ & $0.014658(0.320)$ & $0.229880(0.311)$ \\
\hline $\mathrm{B} 4\left(\mathrm{SC}_{\mathrm{i}, \mathrm{t}-1}\right)$ & $0.333071(0.005)$ & $0.000017(0.001)$ \\
\hline Constant & $1.056962(0.000)$ & $0.922160(0.000)$ \\
\hline
\end{tabular}

Table 2 shows that for off-cluster firms, in contrast to on-cluster firms, almost all p-values were greater than cut-off in both fixed and random effect models. Shareholder contributions exhibited a correlation but interestingly Innov did not, showing that Innov is a correlating factor for on-cluster firms but not for off-cluster (compare Tables 1 and 2). In order to investigate the actual difference between on- and off-cluster firms in this respect, good p-values were taken and Eq 3 was used.

$$
\ln \left(e m p_{i, t}\right)=B_{1} \times A g e_{i, t}+B 2 \times S C_{i, t}+B_{3} \times S E S_{i, t-1}+U_{i}+C \quad \text { Eq. } 3
$$

Where $S C$ is the shareholders contribution for firm $(i)$ in year $(t)$, SES is the social expenses score for firm (i), in the previous year $(t-1)$, and Age is the age (years since founding) of the firm. Hausman test concluded that random effect is the most appropriate, and the preference is to use the random effect model over OLS regression. This resulted in the coefficient $B 1=0.008154, B 2=0.000011$, and $B 3=-0.006861$. These results mean firstly that for the off-cluster firms, as the firm ages, it employs more people, and similarly is the shareholders contribution (SC). However, the socializing score has a negative impact, meaning that the more social expenditure has been in the previous year, the lower the expected growth the year after.

\subsection{Firms Financial Growth}

To model the factors influencing financial growth rates, the procedure defined in 3.1 , was generally followed, applying equation 4 :

\footnotetext{
$\ln \left(\right.$ Turnover $\left._{i, t}\right)=B_{1} \times E^{2} p_{i, t}^{2}+B_{2} \times E m p_{i, t}+B_{3} \times A g e_{i, t}^{2}+B_{4} \times A g e+B_{5} \times$ Innov $_{i, t-1}+$

$B_{6} \times \operatorname{Innov}_{i, t}+B_{7} \times \ln \left(R \& D_{i, t-1}\right)+U_{i}+C$

Eq. 4
} 
The Hausman test results were $\left(P r o b>c h i^{2}=0.0242\right)$ indicating that fixed effect model is the one to use (table 3 ). When the fixed effect of time fixed was investigated, the result was $($ Prob $>F=0.8970)$ indicating an absence of time fixed effect. Therefore, we only generated the individual fixed effect $\left(U_{i}\right)$, which generated values between minimum = (minus) -4.9, and maximum= 2.7 .

Table 3: The financial growth of on-cluster firms, showing random and fixed effect models coefficients.

\begin{tabular}{|c|c|c|}
\hline Parameter & $\begin{array}{l}\text { Fixed Effect } \\
\text { Coefficient(p-value) }\end{array}$ & $\begin{array}{l}\text { Random Effect } \\
\text { Coefficient(p-value) }\end{array}$ \\
\hline $\mathrm{B} 1\left(\mathrm{Emps}_{\mathrm{i}, \mathrm{t}}{ }^{2}\right)$ & $-0.000204(0.000)$ & $-0.000294(0.000)$ \\
\hline B2 (Empsi,t) & $0.051895(0.000)$ & $0.075572(0.000)$ \\
\hline B3 $\left(\right.$ Age $\left._{i, t}{ }^{2}\right)$ & $-0.002714(0.052)$ & $-0.002299(0.066)$ \\
\hline $\mathrm{B} 4\left(\operatorname{Age}_{\mathrm{i}, \mathrm{t}}\right)$ & $0.087002(0.032)$ & $0.069730(0.050)$ \\
\hline B5 (Innov $\left.{ }_{i, t-1}\right)$ & $0.025648(0.015)$ & $0.022256(0.032)$ \\
\hline B6 $\left(\operatorname{Innov}_{i, t}\right)$ & $-0.118195(0.001)$ & $-0.121068(0.000)$ \\
\hline B7 $\left(\ln \left(R \& D_{i, t-1}\right)\right.$ & $0.055262(0.019)$ & $0.049959(0.026)$ \\
\hline Constant & $7.415426(0.000)$ & $7.056322(0.000)$ \\
\hline
\end{tabular}

Table 3 summarizes the relationship between firms' financial growth and size, age and innovation. It shows a positive correlation and effect of innovation (measured as a value of patents to turnover) in previous year $(t-1)$ with financial growth, where $R^{2}=$ $87 \%$, and $R^{2}$-adj $=85 \%$, again indicating a strong fit.

As before, for off-cluster firms, poor p-values were found for some of the parameters using both random and fixed effect models, possibly indicative of differences in the effect of factors between on-and off-cluster firms (see table 4). 
Table 4: Off-cluster firms' financial growth (random and fixed effect) applying the model obtained from eq. 4.

\begin{tabular}{|c|c|c|}
\hline Parameter & $\begin{array}{l}\text { Fixed Effect } \\
\text { Coefficient(p-value) }\end{array}$ & $\begin{array}{l}\text { Random Effect } \\
\text { Coefficient(p-value) }\end{array}$ \\
\hline $\mathrm{B} 1\left(\mathrm{Emps}_{\left.\mathrm{i}, \mathrm{t}^{2}\right)}\right.$ & $-0.000787(0.000)$ & $-0.001049(0.000)$ \\
\hline B2 $\left(\mathrm{Emps}_{\mathrm{i}, \mathrm{t}}\right)$ & $0.128826(0.000)$ & $0.163186(0.000)$ \\
\hline B3 $\left(\right.$ Age $^{2}, \mathrm{i}, \mathrm{f}$ & $0.001131(0.204)$ & $0.000663(0.413)$ \\
\hline B4 $\left(\mathrm{Age}_{\mathrm{i}, \mathrm{t}}\right)$ & $-0.050358(0.042)$ & $-0.033691(0.119)$ \\
\hline B5 $\left(\operatorname{Innov}_{i, t-1}\right)$ & $-0.872358(0.803)$ & $0.505128(0.436)$ \\
\hline B6 $\left(\right.$ Innov $\left._{i, t}\right)$ & $1.303690(0.747)$ & $1.537478(0.490)$ \\
\hline B7 $\left(\ln \left(R \& D_{i, t-1}\right)\right.$ & $0.049988(0.074)$ & $0.057220(0.027)$ \\
\hline Constant & $6.984484(0.000)$ & $6.550670(0.000)$ \\
\hline
\end{tabular}

Thus, the financial growth of off-cluster firms' group was analysed using Eq 5.

$$
\ln \left(\text { Turnover }_{i, t}\right)=B_{1} \times \text { Emps }_{i, t}^{2}+B_{2} \times \text { Emps }_{i, t}+B_{3} \times A g e_{i, t}+B_{4} \times \ln \left(R \& D_{i, t-1}\right)+U_{i}+C
$$

Eq. 5

The results show $B 1=-0.001799, B 2=0.271634, B 3=-0.0463063, B 4=0.0977126$ where Emps is the number of employees for firm $(i)$ in year $(t)$, Age is the firm age (i), in year $(t)$, and $\ln \left(R \& D_{i, t-1}\right)$ is the growth rate in $R \& D$ for firm $(i)$ in the previous year $(t-1)$, with fixed effect and no time fixed effect. The results show a complex (quadratic) relationship between the number of employees (this is similar to the results obtained for on-cluster firms), but also the negative linear relationship between firms age and financial growth indicates that the older the firm gets, the less it will grow financially. As in the case with on-cluster firms, the growth in $R \& D$ in the previous year resulted in a positive growth in financial performance.

\subsection{Innovation in Firms}

The ratio of the value of patents to turnover was used as a 'score' to measure the innovation and this was detailed further into innovation input (the costs of networking and $R \& D$ ), and innovation outputs (income from patented products and processes as well as licencing of patents). Innovation output has already been described (equation 2). For innovation input we used the following equations $(6 \& 7)$ : 
$S E S_{i, t}=\frac{S E_{i, t}}{\text { Turnover }_{i, t}}$

Eq. 6

Where $S E S$ is the social expenses score in year $(t)$, and $S E$ is the actual value of the social expenses.

$R \& D S_{i, t}=\frac{R \& D_{i, t}}{\text { Turnover }_{i, t}}$

Where $R \& D S$ is the $R \& D$ investment score for firm $(i)$ in year $(t)$. However, no relationship was found between $\mathrm{R} \& \mathrm{D}$ score and Innov score.

Table 5: Innovation in on-cluster firms, showing Random and Fixed effects and their coefficient values.

\begin{tabular}{|l|l|l|}
\hline Parameter & $\begin{array}{l}\text { Fixed Effect } \\
\text { Coefficient (p-value) }\end{array}$ & $\begin{array}{l}\text { Random Effect } \\
\text { Coefficient (p-value) }\end{array}$ \\
\hline B1 $\left(\mathrm{SES}_{\mathrm{i}, \mathrm{t}}\right)$ & $-0.052944(0.000)$ & $-0.050111(0.000)$ \\
\hline $\mathrm{B} 2\left(\mathrm{SES}_{\mathrm{i}, \mathrm{t}}\right)$ & $3.693099(0.000)$ & $3.603987(0.000)$ \\
\hline Constant & $-0.568068(0.000)$ & $-0.566238(0.000)$ \\
\hline
\end{tabular}

After checking regressions, equation 8 was used to measure innovation impact.

$$
\text { Innov }_{i, t}=B_{1} \times S E S_{i, t}^{2}+B_{2} \times S E S_{i, t}+U_{i}+C
$$

Eq. 8

Where SES is the social expenses score for firm $(i)$, in year $(t)$. The test resulted $\left(R^{2}=\right.$ $78 \%$ ), which indicates a model with good fit, and the Hausman test reports (Prob $>c h i^{2}=$ 0.0000 ), rejected the null hypothesis, and concluded that fixed effect model is the most appropriate model. Checking for presence of time fixed effect produced a $p$-value of (0.9198) suggesting that time fixed effect is not important.

It was then checked if the same model works for the off-cluster group, applying both fixed and random effect models. Table 6 shows that for off-cluster firms the test resulted in a bad fit due to poor parameter $p$-values (table 6) 
Table 6: Off-cluster firms innovation capabilities model; applying Eq.8 for the off-cluster firms.

\begin{tabular}{|l|l|l|}
\hline Parameter & $\begin{array}{l}\text { Fixed Effect } \\
\text { Coefficient(p-value) }\end{array}$ & $\begin{array}{l}\text { Random Effect } \\
\text { Coefficient(p-value) }\end{array}$ \\
\hline B1 $\left(\mathrm{SES}_{\mathrm{i}, \mathrm{t}}\right)$ & $-1.38 \times 10^{-6}(0.978)$ & $2.78 \times 10^{-6}(0.954)$ \\
\hline B2 $\left(\mathrm{SES}_{\mathrm{i}, \mathrm{t}}\right)$ & $0.000164(0.978)$ & $-0.000332(0.953)$ \\
\hline Constant & $0.00521 \quad(0.005)$ & $0.011828 \quad(0.156)$ \\
\hline
\end{tabular}

Models were then checked for any sign of correlations between innovation (Innov) and (a) investment made by shareholders or groups, (b) firms maturity (measured as age), and (c) the size of the firms. However, none of these factors produced any statistically significant $p$-values. Thus, an evaluation had to be performed in order to evaluate the actual factors which influence firms' innovation capabilities for the off-cluster firms groups, which resulted Eq 7:

$$
\begin{array}{ll}
\text { Innov }_{i, t}=B_{1} \times R \& D_{i, t}+B_{2} \times S C_{i, t}+U_{i}+C & \text { Eq. } 7
\end{array}
$$

Where $B 1=-4.17 \times 10^{-6}, B 2=-2.18 \times 10^{-6}, S C$ is the shareholders contributions, and $R \& D$ is the $R \& D$ investment for firm (i), in year $(t)$ with random effect as proved by Hausman test. Both parameters show a negative correlation with innovation capabilities, however the coefficient are very small (closed to zero) meaning that their impact is most likely random, and there are no significant factors influencing innovation in off-cluster firms.

\subsection{Plotting Functions}

Maple software (maplesoft.com) was used to plot functions. and the command used for plotting is:

$>\operatorname{plot}\left(.118949^{*}<\mathrm{VAR}>-0.2864 \mathrm{e}-2^{*}<\mathrm{VAR}>\wedge 2, \mathrm{VAR}=\mathrm{MIN} . . \mathrm{MAX}\right)$

VAR is any variable that needs to be plotted i.e Age, or emps and MIN represent the minimum value of the variable and MAX is the maximum value of that specific variable.

A description of Maple plot commands can be found on https://www.maplesoft.com/support/help/maple/view.aspx?path=plot\%2Fdetails. 


\section{Results and Analysis.}

\subsection{Employment}

Confirming earlier findings (Davila et al., 2003; Grilli and Murtinu, 2014), the results presented here show that receiving investments through shareholders positively impact the firms' employment growth. Firms that are on-cluster innovate in order to grow and thus investments and innovations are positively related to employment growth (see also Porter, 2003).

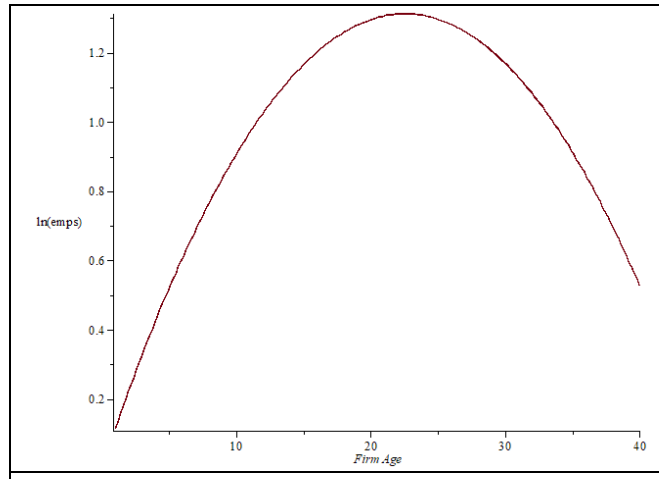

Figure 1 Pertaining to on-cluster firms; age VS financial growth as based on $\left(B_{1} \times A g e_{i, t}^{2}+B_{2} \times A g e_{i, t}\right)$ part of Eq.1. showing the quadratic relationship between the age and employment growth for oncluster firms.

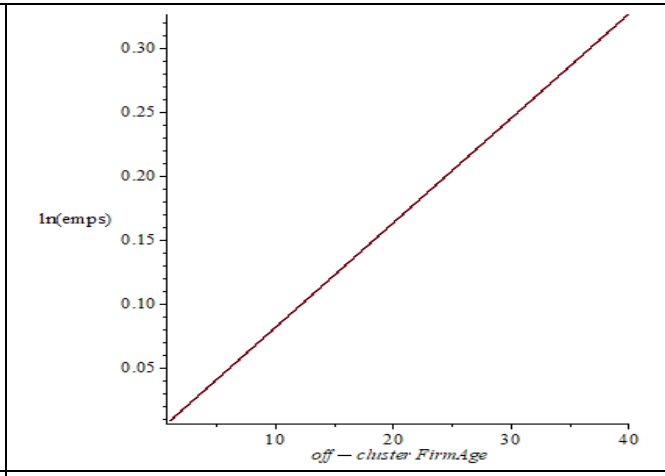

Figure 2 Pertaining to off-cluster firms; age VS financial growth as based on $\left(B_{1} \times A g e_{i, t}\right)$ part of Eq.3, which shows the nature of linear relationship between age and firms' employment growth for the off-cluster firms.

The age of a firm has a more complex relationship with employment growth $\ln ($ emps $)$. Figure 1 presents the quadratic function obtained from using the values $B 1$, and $B 2$ showing that employment in a firm grows until the firm reaches an age of around 20 years, and thereafter it starts to slow down. Figure 1 was obtained by plotting part of Eq. 1 using maple software and plot function, and using the values $B 1$ and $B 2$ without any constant in order to better illustrate the relationship. Thus, this does not represent the plot of the points inside the cluster, but part of the econometrics model obtained in Eq. 1 for investigating the relationship between firms' age (from formation). These results are consistent with those reported by (Diez-Vial and Fernández-Olmos, 2017), who found that young firms benefit most from being located in clusters, but that these benefits become less when firms mature. (Löfsten and Lindelöf, 2002) also reported that younger firms grow faster inside science parks. Other interpretations are also possible, for example that while some on-cluster firms mature and plateaux-out, others that are more successful simply leave the cluster.

For off-cluster firms, the relationship between firms' age and growth is more linear; plotting the equation $0.008154 \times A g e_{i, t}$ which could indicate that across the age- 
range, off-cluster firms perform better. However, that is not the outcome when comparing age to its corresponding value of $\ln (\mathrm{emp})$. For example, comparing the outcome for firms at $($ age $=20)$ for off- and on-cluster shows that $\ln ($ emps $)=0.17$ for off-cluster firms but around 1.1 for on-cluster firms, showing that on-cluster firms do grow faster (using $\ln ($ emps $)$ ) in mid-life, while off-cluster firms grow in a linear manner throughout their life cycle.

Innovation has a negligible impact on employment in off-cluster firms, indeed the growth of off-clusters firms is mainly influenced by investments from shareholders, which increases upon firm maturity. This may be explained by the nature of the offcluster firms, $75 \%$ of which are by micro-firms and thus may be sub-contractors or involved in similar support functions. Other factor influencing the growth of off-cluster firms is the social expenses score, which negatively influences employment development (in stark contrast to the situation in on-cluster firms).

\subsection{Financial growth}

Table 3 shows that when an on-cluster firm innovates it incurs a short-term financial penalty but increased financial growth is probable in the subsequent year(s). In particular the relationship with $\mathrm{R} \& \mathrm{D}$ growth $\left(\ln \left(R \& D_{i, t-1}\right)\right)$ confirms that if a firm $\mathrm{R} \& \mathrm{D}$ investment has grown in the previous year, then the result is higher turnover (income) in the next year(s). This is in agreement with common interpretations of e.g. investing in a patent one year and reaping the benefit in subsequent years, as is also the case for employment growth (previous section) and is generally in line with previous findings of a lag-period before benefits appear (see Baptista and Swann, 1998; Lamperti et al., 2015) underlining the importance of continuous innovation in sustaining business cluster development (Delgado et al., 2010; Delgado et al., 2014, García-Manjón and Romero-Merino, 2012).

However, and as shown in figure 3, the relationship between the maturity of a firm and its financial growth is quadratic and more complex.

\begin{tabular}{|c|c|}
\hline 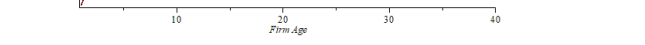 & 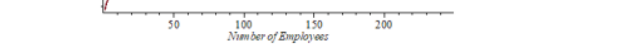 \\
\hline $\begin{array}{l}\text { Figure 3: Pertaining to on-cluster firms; age } \\
\text { VS financial growth as based on } \\
\left(B_{3} \times A g e_{i, t}^{2}+B_{4} \times A g e\right) \text { part of Eq.4, which } \\
\text { presents the quadratic relationship between } \\
\text { on-cluster firm age and financial growth. }\end{array}$ & $\begin{array}{l}\text { Figure 4: Pertaining to on-cluster firms; age } \\
\text { VS financial growth as based on } \\
\left(B_{1} \times E m p_{i, t}^{2}+B_{2} \times E m p_{i, t}\right) \text { part of Eq. } 4 \\
\text { showing the quadratic relationship between } \\
\text { on-cluster firm size and financial growth. }\end{array}$ \\
\hline
\end{tabular}


Figure 3 (plotted using Maple, see 3.5) uses the values B3 and B4 from Eq.4 and age, which ranges from zero (0) to 40 years old i.e. encompasses the total age range within the data source. Figure 3 shows that when firms get older, financial growth slows down. This may be artefactual or, put simply, it is easier to double the turnover of a firm with 1 million per year, than to double the turnover of a firm with 100 million per year. To investigate this further, figure 4 was plotted using the variables $B 1$ and $B 2$ and using the values of zero (0) employee number up to 250 employees, which represent the (min, $\max$ ) range in the data source. Comparing Figure 3 with Figure 4 indicates that size and maturity exhibit optima in on-cluster firms: On-cluster firms grow from age zero to around seventeen years old and from size one employee to around hundred and thirty employees, then level out as growth stops. One hypothesis could be that at this stage, owners either decide on a strategy of 'capped growth' (Mellor, 2011; Mellor, 2014a) staying within the cluster, or decide on a riskier high-growth strategy outside the cluster.

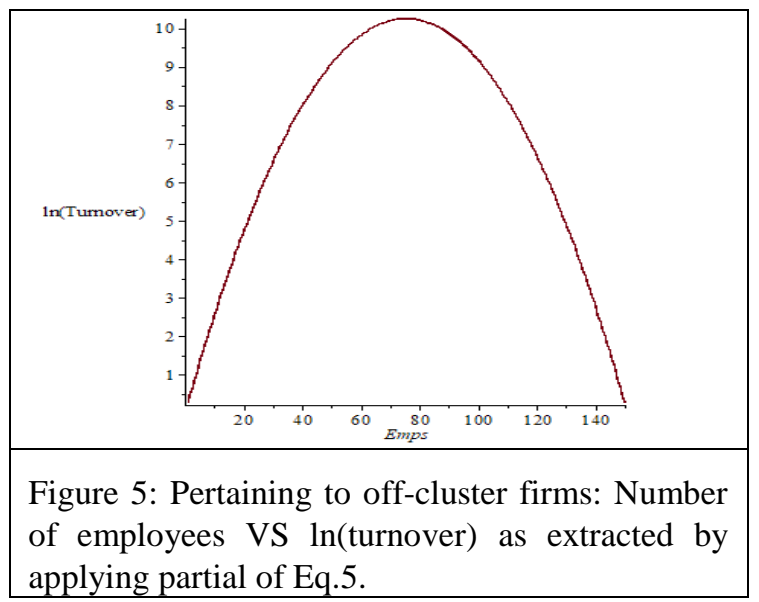

Investigating the difference between on- and off-cluster firms, figure 5 uses Eq. 5 to plot the values $B 1=-0.001799, B 2=0.271634$ and uses the number of employees $(0,150)$ and illustrates that the optimal size for off-cluster firms is smaller than for oncluster firms, being around 70 employees (as compared to 130 for on-cluster). This indicates again that on-cluster firms have an improved growth curve relative to the firm size, although these plots do not take other factors into account. Indeed, for off-cluster firms the production of innovations is not related to performance, which again could indicate that off-cluster firms may contain a significant proportion of sub-contractors.

The econometrics model (Eq. 4) shows the crucial role of innovation as the main determinant of firms' financial development. This is confirmed by interpreting the coefficient of innovation score as well as the growth in $R \& D$, while previous year innovation is the main determinant of the financial growth (albeit that current year innovation has a negative impact) due to the lag in the impact of innovation. Similar to the employment growth, firm size and age have a non-linear impact, which again is consistent with previous results (Löfsten and Lindelöf, 2002), but it differs from previous studies in that this model highlights the need for innovation and investment in R\&D in 


\section{Author}

order for a firm to grow. This confirms that on-cluster firms are more innovation-driven than off-cluster firms (see Al-kfairy et al., 2018, Guadix et al., 2016; Bigliardi et al., 2006; Vásquez-Urriago et al., 2016).

\subsection{Innovation metrics}

Al-kfairy et al.. (2018) showed that on-cluster firms produced a significantly higher innovation output than off-cluster ones and that on-cluster innovation investment produced higher outputs than it did for off-cluster firms. At group level, on-cluster firms also maintain a better financial performance. This is supported by the data in tables 5 and 7 , which a show a lack of correlation due to poor $p$-values, indicating that innovation in on- and off-cluster firms have different dependencies. However, no relationship was found between $R \& D$ score and Innov score. This could indicate that for on-cluster firms, innovation score depends on networking (socializing). To test this, the relationship between SES and Innov was plotted. Figure 6 shows the simulated SES scores from 1\% to $80 \%$ against innovation. Figure 6 shows that networking is the most important factor to achieve a higher innovation score.

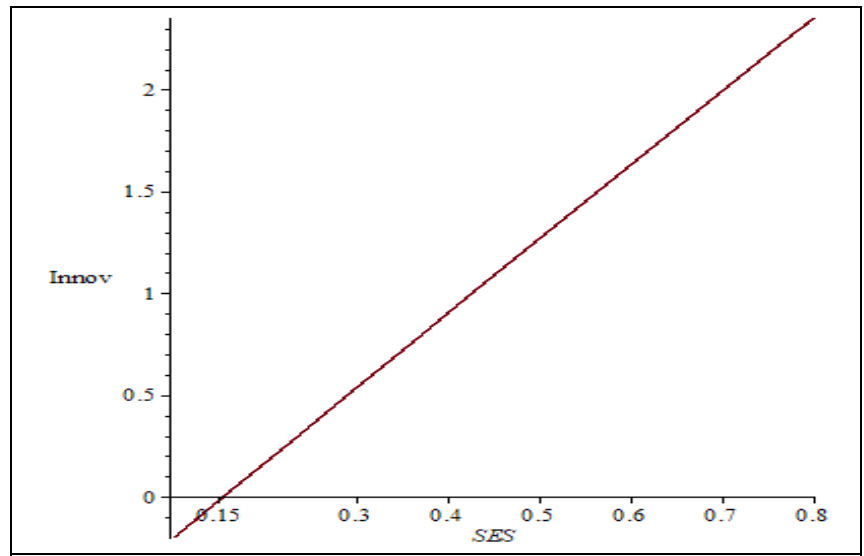

Figure 6: Showing the effect of SES (measured as eq.6) against Innovation Capabilities (measured as eq.2) for oncluster firms (minus innovation score values are for illustration only).

Figure 6 shows that in order to provoke innovation, on-cluster firms need to spend more than $15 \%$ of their turnover on organizing social events, networking, partnership with other firms, etc. Figure 6 was plotted using variables $B 1, B 2$, and the constant (full Eq.6) using the range of (0- 80\%). This range was chosen because some firms may not have any social events $(0 \%)$ or very many $(80 \%)$. Thus, the selection shows the overall trend, although it is clear that for some networking activities informal channels could be used that do not incur direct overheads e.g. lunch time meetings, or personal friendship. Figure 6 shows that expenditure on social activities brings rewards in terms of 
innovation. Moreover, as the results derived from eq. 1 and eq. 4 show, there are positive relationships between on-cluster firms' innovation and both employment and financial growth, which in turn indicates that the growth of on-cluster firms is largely dependent on innovation capabilities. This supports earlier results showing that for single organizations, innovations accrued through networks are almost as valuable as "home grown" innovations (Mellor, 2015). This indicates that the networking is the most important factor inside business cluster for fostering more innovation, which confirms earlier conclusions that it's the most important factor for sustaining innovation, as it represents a good way for knowledge spill-over to occur both vertically and horizontally by intra-firm networking as well as between firms (see Eisingerich et al., 2010; Ting Helena Chiu, 2008; Casanueva et al., 2013; Mellor, 2015).

For off-cluster firms, there was a negligible correlation between the effects of $\mathrm{R} \& \mathrm{D}$, shareholders investments or social networking on firms' innovation and employment or financial growth.

\section{Discussion and Conclusion}

This study is a data driven (empirical) study, which is based on the data available, however there are factors that are not in the Ratsit database, but which have been found to be effective in sustaining business cluster development include e.g. entrepreneurial training (Klofsten, 2000), connection with higher education institutes (Stam and Garnsey, 2009; Moore et al., 2004), entrepreneurship (Maskell, 2001; Mellor, 2019) and cluster specializations (Carroll et al., 2008). Nonetheless, these results are helpful for both policy makers and researchers alike and can be extended in many directions. The summary presented in table 7 distinguishes between the different factors that influence both onand off-cluster firms, showing that on-cluster success factors are more consistent than the off-cluster ones. For example, shareholders contribution impact is always positive on employment growth for on-cluster firms, which makes it much easier to decide if the best strategy is e.g. more investment, where this may not be the best strategy in an off-cluster firm. Similar results were obtained for firms' ages and overall the results point to oncluster firms' development being more deterministic, while for the off-cluster firms, impact is more random, as presented in the econometric models in Section 4.

The results are summarized in figure 7, illustrating that innovation capability is a major determinant for both financial and employment growth. On-cluster innovation capacity is mainly influenced by networking (measured as social expenditure). This highlights the importance of networking for on-cluster firms, which implies that firm managers as well as cluster managers should facilitate social events and networking activities both between and within companies. These findings are consistent with earlier results. For example, Al-kfairy et al. (2017) found networking to be the main determinant of innovation capabilities for business clusters at the aggregate level, and these results confirm the previous findings at the micro-level (see also Bell, 2005; Squicciarini, 2008; Dettwiler et al., 2006). 
Author

Table 7: Summary of success factors findings showing the impact of off-cluster firms success factors, while on-cluster success factors are more stable (the sign of the impact does not change)

\begin{tabular}{|c|c|c|}
\hline Factor examined & On cluster & Off cluster \\
\hline Shareholders' investment & $\begin{array}{l}\text { Positive linear (effecting } \\
\text { employment growth) }\end{array}$ & $\begin{array}{l}\text { Positive linear (effecting } \\
\text { employment growth), } \\
\text { negative linear for } \\
\text { innovation capabilities. }\end{array}$ \\
\hline Firms' age & $\begin{array}{lr}\text { Quadratic } & \text { (effecting } \\
\text { employment } & \text { growth), } \\
\text { quadratic } & \text { (effecting } \\
\text { financial growth) } & \end{array}$ & $\begin{array}{lr}\text { Positive } & \text { linear (effecting } \\
\text { firms' } & \text { employment } \\
\text { growth), negative linear } \\
\text { (effecting } \\
\text { growth). }\end{array}$ \\
\hline Firms' sizes & $\begin{array}{l}\text { Quadratic (effecting } \\
\text { financial growth) }\end{array}$ & $\begin{array}{l}\text { Quadratic (effecting } \\
\text { financial growth) }\end{array}$ \\
\hline $\begin{array}{l}\text { Innovation capabilities (eq, } \\
\text { 2) }\end{array}$ & $\begin{array}{l}\text { Positive linear (effecting } \\
\text { employment and financial } \\
\text { growth) }\end{array}$ & NA \\
\hline $\begin{array}{l}\text { Social Expenses } \text { Score } \\
(\text { SES) (eq. 6) }\end{array}$ & $\begin{array}{l}\text { Positive linear (effecting } \\
\text { innovation capabilities eq. } \\
\text { 2) }\end{array}$ & $\begin{array}{l}\text { Negative linear (effecting } \\
\text { firms employment growth), } \\
\text { negative linear (effecting } \\
\text { innovation capabilities) }\end{array}$ \\
\hline $\ln (\mathrm{R} \& \mathrm{D})$ & $\begin{array}{l}\text { Positive linear (effecting } \\
\text { financial growth) }\end{array}$ & $\begin{array}{l}\text { Positive linear (effecting } \\
\text { financial growth). }\end{array}$ \\
\hline $\mathrm{R} \& \mathrm{D}$ & NA & $\begin{array}{l}\text { Negative linear (effecting } \\
\text { innovation capabilities) }\end{array}$ \\
\hline
\end{tabular}

NA = Not Applicable (no appreciable impact) 


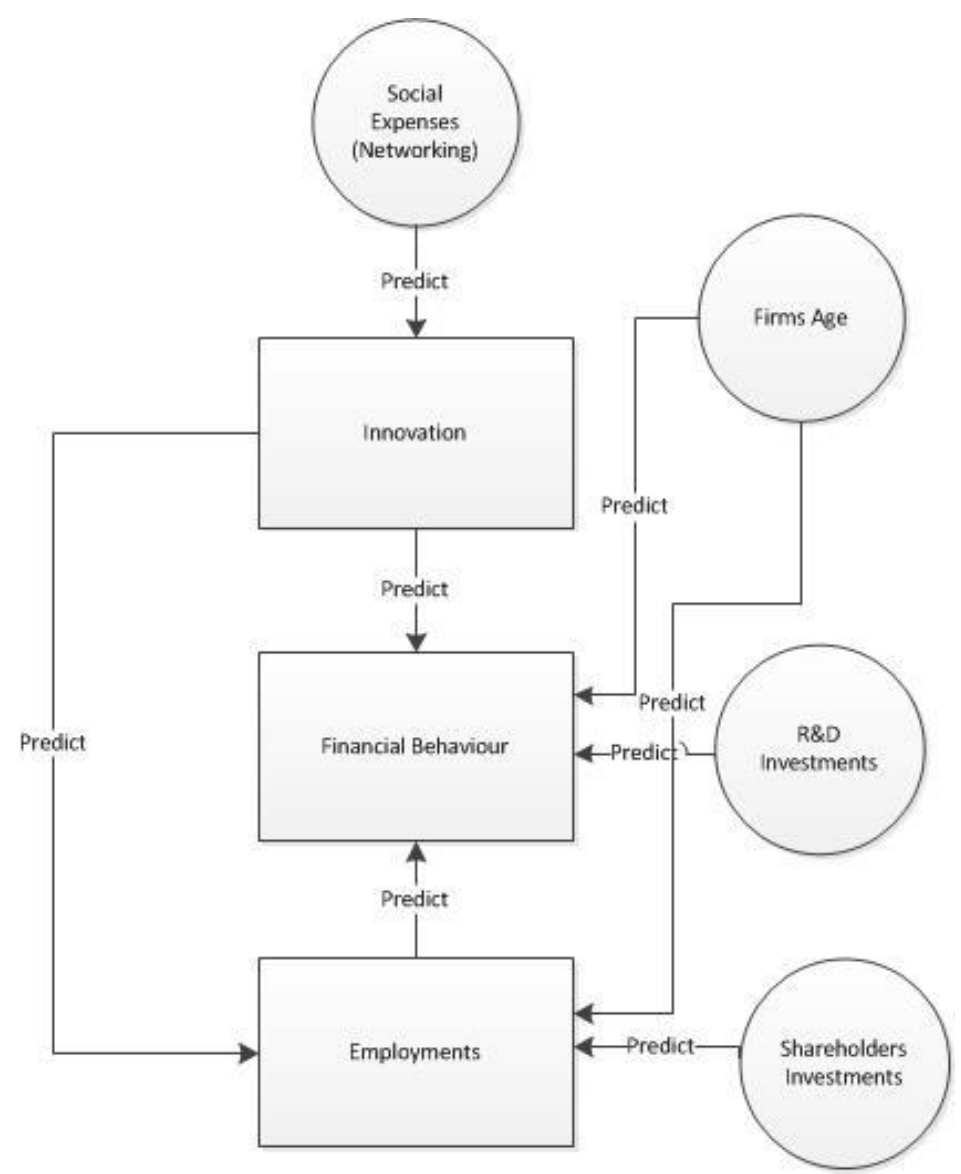

Figure 7. A flow diagram summarising the success factors found for on-cluster firms in a mature STP.

In determining planning around local employment (Diez-Vial and FernándezOlmos, 2017) policy-makers should note that results presented here show that growth (independently of how this is measured) proceeds apace up to age $\sim 17$, whereupon growth in turnover starts to decline. Thus, our initial hypothesis is that firms grow oncluster and innovate by networking, after which they can either stay in the cluster and plateau-out or, if they have achieved very successful innovations, they can "graduate" and move away from the cluster (and perhaps away from the region). Unfortunately, this hypothesis cannot be investigated with the data at hand, and represents future research. Furthermore, this study uses one case study using one industrial code and may not be wholly portable to other industries or cases. However, this study can be extended in many directions, for example, studying the impact of networking intensity together with social expenses and organisational factors like ambidexterity, on firms' innovation capabilities. This study can be replicated using the same data source, conditions and parameters, although it may be more interesting to consider other methodologies such as 3D 
modelling (see e.g. Mellor, 2014a) to map the overall situation of firms and clusters using axes of e.g. employment, turnover and innovation.

Factors such as R\&D, investments, and shareholders contribution highlight the importance of having on-cluster firms supported by investment bodies because these lead to increasing both employment and financial growth. This in turn supports the triple helix view of business clusters connecting public, venture capitals and higher education institutions as propounded by (Klofsten et al., 1999; Etzkowitz and Leydesdorff, 2000; Kim et al., 2014) and are consistent with the results of (Al-kfairy et al., 2019) who in a companion paper to this, showed that especially during the early stages of a cluster, the most efficient topology for an STP is a central initiative surrounded by a star structure of companies. This is important because different networking structures would have different impact on how knowledge flows between firms and indeed the role of ambidexterity (see Will et al, 2019) in STPs has hitherto been neglected.

\section{Acknowledgements}

We gratefully acknowledge innumerable helpful discussions with Dr Matthias G. Will, Martin-Luther-Universität Halle-Wittenberg, Germany.

\section{References}

Al-kfairy, M., Khaddaj, S. and Mellor, R. B. (2017) 'Variables Affecting HighTech Cluster Innovation: A Statistical Approach.' In: 7th International Conference on Law, Business, Marketing and Corporate Social Responsibilities. [online] London: HEAIG. Available at: http://heaig.org/images/proceedings_pdf/H12175121.pdf.

Al-kfairy, M., Khaddaj, S. and Mellor, R. B. (2018) 'A Longitudinal Study of Corporate Benefits Accrued by Firms Inhabiting a Mature Science Park'. In: Proceeding of the $19^{\text {th }}$ European Conference on Knowledge Management. University of Padua, Italy. 6-7 September 2018. Vol. 1, PP. 76-84.

Al-kfairy, M., Khaddaj, S. and Mellor, R. B. (2019) 'Computer Modelling Reveals the Optimal Development for the Organisational Structure in Business Clusters'. International Journal of Knowledge-Based Development (in press).

Baptista, R. and Swann, P. (1998) 'Do firms in clusters innovate more?', Research Policy, Vol.27 No.5, pp. 525-540.

BBC (2010) Six technium business centres closing in Wales. Available at: http://www.bbc.com/news/uk-wales-11790468 (Accessed: 30 March 2018).

Bell, G.G. (2005) 'Clusters, networks, and firm innovativeness', Strategic Management Journal, Vol. 26 No.3, pp. 287-295. 
Bigliardi, B. et al. (2006) 'Assessing science parks' performances: directions from selected Italian case studies', Technovation, Vol.26 No.4, pp. 489-505.

Carroll, M.C., Reid, N. and Smith, B.W. (2008) 'Location quotients versus spatial autocorrelation in identifying potential cluster regions', The Annals of Regional Science, Vol. 42 No. 2, pp. 449-463.

Casanueva, C., Castro, I. and Galan, J.L. (2013) 'Informational networks and innovation in mature industrial clusters', Journal of Business Research, Vol. 66 No. 5, pp. 603 - 613.

Cojocaru, A. and Ionescu, S. (2016) 'The Advantages of Business Clusters', FAIMA Business \& Management Journal, Vol. 4 No. 2, pp. 31-47.

Davila, A., Foster, G. and Gupta, M. (2003) 'Venture capital financing and the growth of startup firms', Journal of Business Venturing, Vol. 18 No. 6, pp. 689-708.

Delgado, M., Porter, M.E. and Stern, S. (2014) 'Clusters, convergence, and economic performance', Research Policy, Vol. 43 No. 10, pp. 1785-1799.

Delgado, M., Porter, M.E. and Stern, S. (2010) 'Clusters and entrepreneurship', Journal of Economic Geography, Vol. 10 No. 4, pp. 495-518.

Dettwiler, P., Lindelöf, P. and Löfsten, H. (2006) 'Utility of location: A comparative survey between small new technology-based firms located on and off Science Parks-Implications for facilities management', Technovation, Vol. 26 No. 4, pp. 506-517.

Diez-Vial, I. and Fernández-Olmos, M. (2017) 'The effect of science and technology parks on a firm's performance: a dynamic approach over time', Journal of Evolutionary Economics, Vol. 27 No. 3, pp. 413-434.

Eisingerich, A.B., Bell, S.J. and Tracey, P. (2010) 'How can clusters sustain performance? The role of network strength, network openness, and environmental uncertainty', Research Policy, Vol. 39 No. 2, pp. 239-253.

Etzkowitz, H. and Leydesdorff, L. (2000) 'The dynamics of innovation: from National Systems and "Mode 2" to a Triple Helix of university-industrygovernment relations', Research Policy, Vol. 29 No. 2, pp. 109-123.

Folta, T.B., Cooper, A.C. and Baik, Y. (2006) 'Geographic cluster size and firm performance', Journal of Business Venturing, Vol. 21 No. 2, pp. 217-242.

García-Manjón, J.V. and Romero-Merino, M.E. (2012) 'Research, development, and firm growth. Empirical evidence from European top R\&D spending firms', Research Policy, Vol. 41 No. 6, pp. 1084-1092.

Grilli, L. and Murtinu, S. (2014) 'Government, venture capital and the growth of European high-tech entrepreneurial firms', Research Policy, Vol. 43 No. 9, pp. 1523-1543.

Guadix, J. et al. (2016) 'Success variables in science and technology parks', Journal of Business Research, Vol. 69 No. 11, pp. 4870-4875.

Hobbs, K., Link, A. and Scott, J. (2017) 'Science and technology parks: an annotated and analytical literature review', The Journal of Technology Transfer, Vol. 42 No. 4, pp. 957-976.

Hsiao, C. (2007) 'Panel data analysis — advantages and challenges', Test, Vol, 16 No.1, pp. 1-22.

IASP (2016) IASP. Available at: http://www.iasp.ws/ (Accessed 30 March 2016). 
Kajikawa, Y. et al. (2010) 'Multiscale analysis of interfirm networks in regional clusters', Technovation, Vol. 30 No. 3, pp. 168-180.

Kelly, T.J.C. and Firestone, R.S. (2016) How tech hubs are helping to drive economic growth in Africa. World Development Report background papers. Washington, D.C.: World Bank Group.

Kim, H. et al. (2014) 'The evolution of cluster network structure and firm growth: a study of industrial software clusters', Scientometrics; an International Journal for all Quantitative Aspects of the Science of Science, Communication in Science and Science Policy, Vol. 99 No.1, pp. 77-95.

Klofsten, M. et al. (2015) 'Success factors in cluster initiative management: mapping out the'big five", Industry and Higher Education, Vol. 29 No.1, pp. 65-77.

Klofsten, M. (2000) 'Training Entrepreneurship at Universities: A Swedish Case', Journal of European Industrial Training, Vol. 24 No.6, pp. 337-44.

Klofsten, M., Jones-Evans, D. and Schärberg, C. (1999) 'Growing the Linköping Technopole-A Longitudinal Study of Triple Helix Development in Sweden', The Journal of Technology Transfer, Vol. 24 No.2, pp. 125-138.

Lamperti, F., Mavilia, R. and Castellini, S. (2015) 'The role of Science Parks: a puzzle of growth, innovation and R\&D investments', Journal of Technology Transfer, pp. 1-26.

Löfsten, H. and Lindelöf, P. (2002) 'Science Parks and the growth of new technology-based firms - academic-industry links, innovation and markets', Research Policy, Vol. 31 No.6, pp. 859-876.

Markusen, A. (1996) 'Sticky Places in Slippery Space: A Typology of Industrial Districts', Economic Geography, Vol. 72 No.3, pp. 293-313.

Maskell, P. (2001) 'Towards a knowledge-based theory of the geographical cluster', Industrial and Corporate Change, Vol. 10 No.4, pp. 921-943.

Mellor, R.B. (2014a) 'Knowledge valley theory', International Journal of Knowledge-Based Development, Vol. 2 No. 5, pp. 5-16.

Mellor, R. B. (2014b) 'The use of knowledge assets: modelling the potential effect of adding innovators to low-innovation and high-innovation SMEs', International Journal of Knowledge-Based Development, Vol. 5 No.4, pp. 367-380.

Mellor, R. B. (2015) 'Modelling the value of external networks for knowledge realisation, innovation, organisational development and efficiency in SMEs', International Journal of Knowledge-Based Development, Vol. 6 No.1, pp. 3-14.

Mellor, R. B. (2018) 'Big data modelling the knowledge economy', International Journal of Knowledge-Based Development, Vol. 9 No. 3 pp.206-220

Mellor, R. B. (2019) 'Entrepreneurship', in Mellor, R.B. (ed) Management for Scientists pp 33-48. Emerald Publishers, Bingley, UK.

Moore, G., Davis and Kevin (2004) 'Learning the Silicon Valley Way', in Bresnaha, T. \&Gambardella, A. (eds.) Building High-Tech Clusters:Silicon Valley and Beyond. Cambridge University Press, pp. 1-17.

Morosini, P. (2004) 'Industrial clusters, knowledge integration and performance', World Development, Vol. 32 No. 2, pp. 305-326. 
Mudambi, R. and Swift, T. (2011) 'Proactive R\&D management and firm growth: a punctuated equilibrium model', Research Policy, Vol. 40 No. 3, pp. 429440.

Pitelis, C. (2012) 'Clusters, entrepreneurial ecosystem co- creation, and appropriability: a conceptual framework', Industrial and Corporate Change, Vol. 21 No.6, pp. 1359-1388.

Porter, M.E. (2000) 'Location, competition, and economic development: Local clusters in a global economy', Economic Development Quarterly, Vol. 14 No.1, pp. 15-34.

Porter, M. (2003) 'The Economic Performance of Regions', Regional Studies, Vol. 37 No. 6-7, pp. 549-578.

Porter, M.E. (1998) The competitive advantage of nations. New ed, with a new introduction.. edn. Basingstoke: Basingstoke : Macmillan.

Pugh, R., MacKenzie, N.G. and Jones-Evans, D. (2018) 'From 'Techniums' to 'emptiums': the failure of a flagship innovation policy in Wales', Regional Studies, Vol. 52 No. 7, pp. 1009-1020.

Scoreboard, I.U. (2015) European Commission, Brussels 2015, Electronic resource. Access mode: http://ec. europa. eu/growth/industry/innovation/factsfigures/scoreboards/index_en. htm.

Squicciarini, M. (2008) 'Science Parks' tenants versus out-of-Park firms: who innovates more? A duration model', The Journal of Technology Transfer, Vol. 33 No. 1, pp. 45-71.

Stam, E. and Garnsey, E. (2009) 'Decline and renewal of high-tech clusters: The Cambridge case', In Summer Conference, Copenhagen Business School, http://www2. druid. dk/conferences/viewpaper. php.

Temouri, Y. (2012) 'The Cluster Scoreboard: Measuring the performance of local business clusters in the knowledge economy', OECD Local Economic and Employment Development (LEED) Working Papers, (13), pp. 1-45.

Ting Helena Chiu, Y. (2008) 'How network competence and network location influence innovation performance', Journal of Business \& Industrial Marketing, Vol. 24 No. 1, pp. 46-55.

Torres-Reyna, O. (2007) 'Panel data analysis fixed and random effects using Stata (v. 4.2)', Data \& Statistical Services, Princeton University, Available at https://www.princeton.edu/ otorres/Panel101.pdf.

Vásquez-Urriago, Á. R., Barge-Gil, A. and Modrego Rico, A. (2016) 'Science and Technology Parks and cooperation for innovation: Empirical evidence from Spain', Research Policy, Vol. 45 No. 1, pp. 137-147.

Wadhwa, V. (2013) 'Silicon Valley Can't Be Copied', Technology Review, Vol. 116 No. 5, pp. 87-88.

Wallsten, S. (2004) 'The role of government in regional technology development: The effects of public venture capital and science parks', Building HighTech Clusters: Silicon Valley and Beyond. Cambridge University Press, Cambridge, pp. 229-279.

Will, M. G., Al-Kfairy, M. and Mellor, R. B. (2019) 'How organizational structure transforms risky innovations into performance - a computer simulation', Simulation Modelling Practice and Theory, Vol. 94, pp 264285 